DOI 10.2478/v10040-008-0105-8

\title{
ENGINEERING SYSTEM RELIABILITY STATE IDENTIFICATION METHODOLOGY
}

\section{METODYKA IDENTYFIKACJI NIEZAWODNOŚCI SYSTEMU TECHNICZNEGO}

\author{
Jerzy JAŹWIŃSKI ${ }^{1}$, Janusz SZPYTKO ${ }^{2}$, Józef ŻUREK ${ }^{3}$ \\ $(1,3)$ Air Force Institute of Technology, Warsaw; Poland, \\ (2) AGH University of Science and Technology, Krakow, Poland,
} E-mails: (1) airteam@itwl.polbox.pl, (2)szpytko@agh.edu.pl, (3)jzurek@itwl.polbox.pl

\begin{abstract}
In the process of investigating physical aspects of failures there is a need for measuring various features of objects. For this purpose measuring system, which consists of: operator - measuring instrument was used. In the paper an attempt of determining affectivity of such system was done. Influence of the first and second type errors on affectivity of the measuring system was considered. It was also shown how to decrease these errors. Influence on the affectivity of the reliability measurement of the measuring instrument was analyzed. Graduate and immediate failures were considered. Then some final conclusions were formulated.
\end{abstract}

Keywords: identification of the system technical state, reliability, measurement errors

Streszczenie. Przedmiotem artykułu jest metoda identyfikacji niezawodności systemu technicznego złożonego $\mathrm{z}$ operatora podejmującego decyzję na podstawie informacji pozyskiwanych przez przyrządy pomiarowe wybranych parametrów eksploatacyjnych. Proces decyzyjny może być podejmowany z użyciem błędnych informacji pierwszego $\mathrm{i}$ drugiego rodzaju. Dla potrzeb racjonalizacji procesu decyzyjnego $\mathrm{w}$ warunkach rzeczywistych opracowano przedmiotowy algorytm.

Slowa kluczowe: identyfikacja stanu technicznego systemu, niezawodność, błędy pomiarowe 


\section{Introduction}

In process of use of various kinds of objects, for example manufacturing and transport systems, it is needed to receive the information about their state. Usually that means checking compatibility of a determined object property $C_{i}$ with requirements $W_{i}$, that is $C_{i} \subset W_{i}$, where $i=1,2, \ldots n$, and $n$ - number of properties describing the system.

Measurement, or more strictly - measurement process, may be treated as a special case of an information process (Finkelstein, 1983). We obtain information about state of investigated objects by means of Measuring System MS (Szpytko, 2004). It is illustrated in Figure 1.

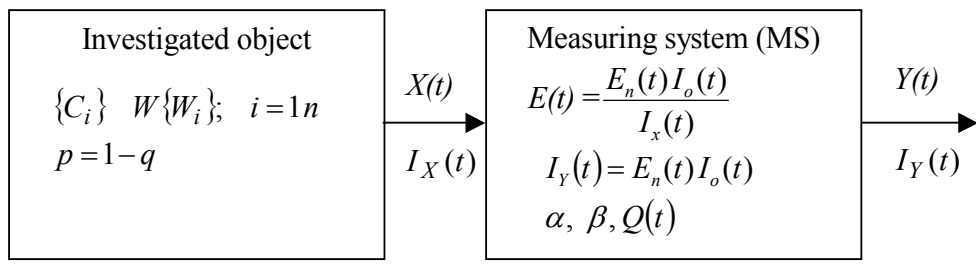

Fig. 1 Investigation of the state of the object

The basic concepts connected with work of MS are the following: $R(t)$ - reliability function of MS, $Q(t)$ - unreliability function of MS, $P$ - reliability of investigated object, $q$ - unreliability of investigated object.

The symbols in the Figure1 and considered problems are described by (Jaźwiński and Ważyńska-Fiok, $1992 \mathrm{a}, \mathrm{b})$. In this paper only final results are presented. At the input of a MS we have process $X(t)$. This process gives the information about the state of investigated objects. This state is compatible with the requirements, with probability $p$ and incompatible with the requirements with probability $q=1-p$. The information $I_{x}(t)$ is given by formulae:

$$
I_{x}(t)=-t[p \ln p+(1-p) \ln (1-p)]
$$

At the output of the MS we receive the process $Y(t)$ as the result of measurement of process $X(t)$.

In the process $Y(t)$ errors occur:

- of the first type denoted by $\alpha$ (qualification of property compatible with requirements as incompatible that is $\left.C_{i} \subset W_{i} \rightarrow C_{i} \not \subset W_{i}\right)$;

- $\quad$ of the second type, denoted by $\beta\left(C_{i} \not \subset W_{i} \rightarrow C_{i} \subset W_{i}\right)$;

- caused by the unreliability $Q(t)=1-R(t)$ of the MS.

The amount of information at the MS output is:

$$
\begin{gathered}
I_{Y}(t)=E_{n}(t) I_{o}(t) \\
I_{o}(t)=F_{t}[H(X, Y)-H(Y)]
\end{gathered}
$$

where $H(X, Y)$ and $H(Y)$ are respectively entropy of the signal received and of the error, given by (Wiśniewski, 1961): 


$$
\begin{gathered}
H(Y)=-[\beta+p(1-\alpha-\beta)] \ln [\beta+p(1-\alpha-\beta]- \\
-[(1-\beta)-p(1-\alpha-\beta)] \ln [(1-\beta)-p(1-\alpha-\beta)] \\
H(X, Y)=-(1-\alpha) \ln p(1-\alpha)-p \alpha \ln p \alpha- \\
-(1-p)(1-\beta) \ln (1-p) \beta \ln (1-p) \beta) \\
E_{n}(t)=\frac{1}{t} \int_{o}^{t} R(\tau) d \tau=\frac{t_{s}}{t}
\end{gathered}
$$

where: $F$ - the state evaluation frequency of investigated object,

$E_{n}(t)$ - the reliability affectivity function,

$t_{s}$ - fraction of time in which MS is in ability state.

The affectivity of measuring system is given by equation (Jaźwiński and Ważyńska-Fiok, 1992; Jaźwiński \& Ważyńska-Fiok, 1993b):

$$
E(t)=\frac{E_{n}(t) I_{o}(t)}{I_{x}(t)}
$$

The components of $E(t)$ are given by formulae (1) and (3). Let us consider the component of reliability affectivity $E_{n}(t)$.

\section{The structure of MS}

The measuring system considered here, is understood in the broadened sense given in the introduction. For such system we propose to introduce a concept of measuring structure. The proposed concept may be utilized for MS'es performing various kinds of measuring tasks. The sense of the measuring structure may be different for various kinds of systems.

In the present paper we consider the MS'es intended for checking ability of objects. In the case of such systems we propose to understand measuring structure in a programme sense. It means that measuring structure is defined by checking strategy. In Table 1 four elementary strategies have been given [2]. The three elementary structures (strategies) may be used.

In the structures presented above, we have structural surplus. The aim of this surplus is to decrease errors of the first and second type. It is possible to create more complex strategies utilizing these elementary ones. Let us denote, for the determined strategy, the probabilities of the first and second types errors by $\mathrm{Q}_{\alpha}$ and $\mathrm{Q}_{\beta}$, respectively. The quantities $\mathrm{Q}_{\alpha}$ and $\mathrm{Q}_{\beta}$ for exemplary set of strategies are presented below in Table 1 .

Among various criteria of choice of the best strategy, we may distinguish the following principles:

a. the minimization of the sum of mean numbers of errors of the first and second types,

b. min $\left(w_{\alpha} Q_{\alpha}+w_{\beta} Q_{\beta}\right)$ where $w_{\alpha}$ and $w_{\beta}$ are weights of errors of the first and second types, respectively,

c. the minimization of the mean cost connected with effects of errors of the first and second types, 
d. the minimization of the information losses as effect of errors of the first and second types.

In consequence of the assumption of surplus structure, we obtain: $Q_{\alpha}(\alpha)<\alpha$ and $Q_{\beta}(\beta)<\beta$. Then the MS affectivity is:

$$
E\left[t, Q_{\alpha}(\alpha), Q_{\beta}(\beta)\right]=\frac{E_{n}(t, R) I_{o}\left\lfloor t, Q_{\alpha}(\alpha), Q_{\beta}(\beta)\right\rfloor}{I_{x}(t, p)}
$$

In result:

$$
E\left[t, Q_{\alpha}(\alpha), Q_{\beta}(\beta)\right]\langle E(t, \alpha, \beta)
$$

The strategies No 2 and No 3 are illustrated in Figure 2 and Figure 3, respectively.

\section{The influence of reliability on the affectivity of measuring system}

If the amount of information per time unit at the MS input is constant, then the disposability of MS is determined by amount of lost information. The MS transfers the information in able state. It means that time interval $[\Delta]$ is divided in two subintervals: interval $\left[0, t_{1}\right]$, in which the information passes to output of MS and interval $\left[t_{l}, t\right]$ in which the information does not pass to MS output in result a failure.

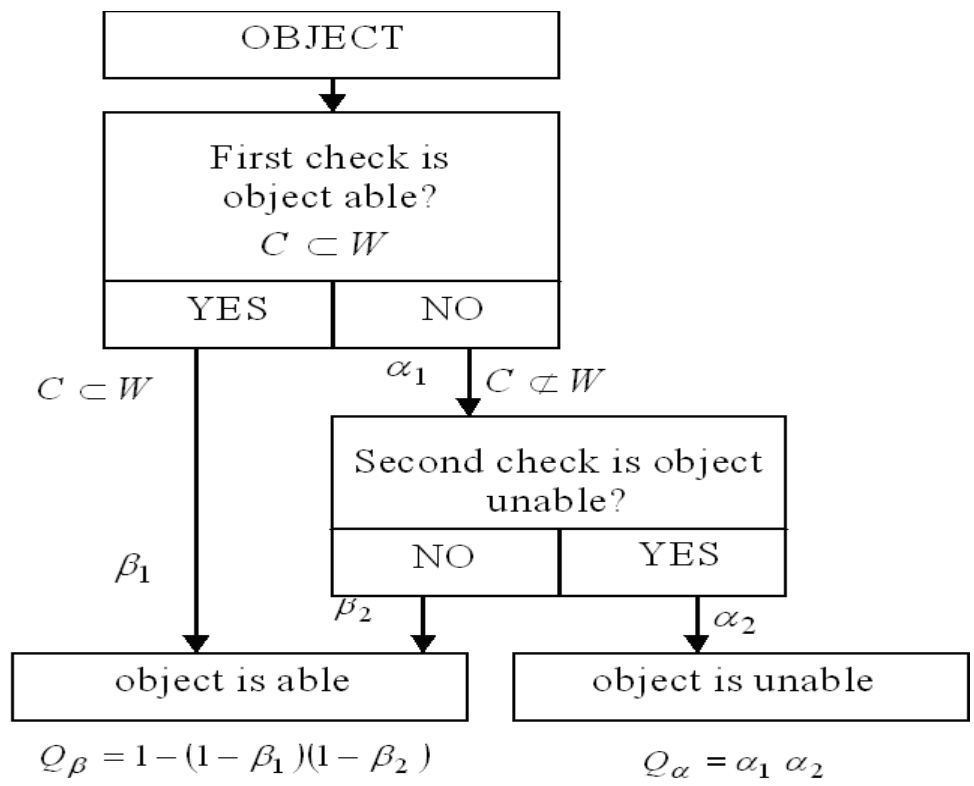

Fig. 2 Illustration of the strategy No 2 (Table 1). 
Table 1. Set of strategies

\begin{tabular}{|c|c|c|}
\hline No & Strategy & Mathematical formulae and comments \\
\hline 1. & $\begin{array}{l}\text { The MS qualifies the object as able (C } \\
\in W \text { ) or unable }(\mathrm{C} \not \subset \mathrm{W}) \text {, when } \\
\text { minimum } \mathrm{m} \text { checks and maximum }(2 \mathrm{~m} \\
\text { 1) check show ability or unability } \\
\text { (Wiśniewski, 1961) }\end{array}$ & $\begin{array}{l}Q_{\alpha}=\alpha^{m} \sum_{i=0}^{m}\left(\begin{array}{c}m+i-1 \\
i\end{array}\right)(1-\alpha) \\
Q_{\beta}=\beta^{m} \sum_{i=0}^{m-1}\left(\begin{array}{c}m+i-1 \\
i\end{array}\right)(1-\beta) \\
\text { the value m we select from condition: } \\
Q_{\alpha}\left\langle\alpha^{*} ; Q_{\beta}\left\langle\beta^{*}\right.\right. \\
Q_{\alpha}{ }^{*} ; Q_{\beta}{ }^{*} \text { - assumed error probability } \\
\text { values }\end{array}$ \\
\hline 2. & $\begin{array}{l}\text { If in the first check the object has been } \\
\text { classified as able we recognize it as } \\
\text { able. If in the first check the object has } \\
\text { been classified as unable we check the } \\
\text { object once more; If the result of the } \\
\text { second check says it is unable, we } \\
\text { recognize the object as unable; If the } \\
\text { result of this check says it is able we } \\
\text { recognize the object as able (Jaźwiński } \\
\text { \& Ważyńska-Fiok, 1994) (Figure 2). }\end{array}$ & $\begin{array}{l}Q_{\alpha}=\alpha_{1} \alpha_{2} \\
Q_{\beta}=1-\left(1-\beta_{1}\right)\left(1-\beta_{2}\right) \\
\text { The error } Q_{\alpha} \text { decreases; the error } Q_{\beta} \\
\text { increases. } \\
\text { Incorrect functioning is dangerous; } \\
\text { The incorrect pause in functioning is } \\
\text { costbar. }\end{array}$ \\
\hline 3. & $\begin{array}{l}\text { If in the first check the object has been } \\
\text { classified as unable, we recognize it as } \\
\text { unable. If in the first check the object } \\
\text { has been classified as able we check } \\
\text { the object once more; If the result of } \\
\text { the second check says it is able we } \\
\text { recognize the object as able; If the } \\
\text { result of this check says it is unable we } \\
\text { recognize the object as unable } \\
\text { (Jaźwiński \& Ważyńska-Fiok, 1994) } \\
\text { (Figure 3). }\end{array}$ & $\begin{array}{l}Q_{\alpha}=1-\left(1-\alpha_{1}\right)\left(1-\alpha_{2}\right) \\
Q_{\beta}=\beta_{1} \beta_{2} \\
\text { The error } Q_{\alpha} \text { increases. } \\
\text { The error } Q_{\beta} \text { decreases. } \\
\text { This situation is dangerous in aviation } \\
\text { or space transport. }\end{array}$ \\
\hline 4. & $\begin{array}{l}\text { The MS belongs to category of } \\
\text { learning system. In such system each } \\
\text { work cycle is followed by correction } \\
\text { of system errors with probability } \mathrm{P}(\alpha) \\
\text { of correcting errors of the first type } \\
\text { and } \mathrm{P}(\beta) \text { of the second type. Number k } \\
\text { of work cycles needed to obtain } \\
\text { assumed values of probabilities of } \\
\text { errors of recognition of the state of the } \\
\text { object can be found from the presented } \\
\text { formulae [(aźwiński \& Ważyńska- } \\
\text { Fiok, 1993b). }\end{array}$ & $\begin{array}{l}Q_{\alpha}=\alpha[1-\alpha P(\alpha)]^{k-1} \\
Q_{\beta}=\beta[1-\beta P(\beta)]^{k-1}\end{array}$ \\
\hline
\end{tabular}


The failures of MS may be divided into the immediate or gradual. Taking it into account, the system reliability is given by:

$$
R(t)=R_{g}(t) R_{m}(t)
$$

where:

$$
R_{g}(t)=1-Q_{B g}(t)-Q_{S g}(t) ; \quad R_{m}(t)=1-Q_{B m}(t)-Q_{S m}(t)
$$

$R_{g}(t)$ - system reliability connected with gradual failures; it is probability that in MS - incompatibility of a property with requirements, in consequence of gradual failures does not occur,

$R_{m}(t)$ - system reliability connected with immediate failures described analogically, $Q_{B g}(t)$ - safety unreliability caused by gradual failures,

$Q_{S g}(t)$ - efficiency unreliability caused by gradual failures,

$Q_{B m}(t)$ and $Q_{S m}(t)$ are analogical quantities in the case of immediate failures,

Let us consider the reliability characteristic of various kinds of MS failures.

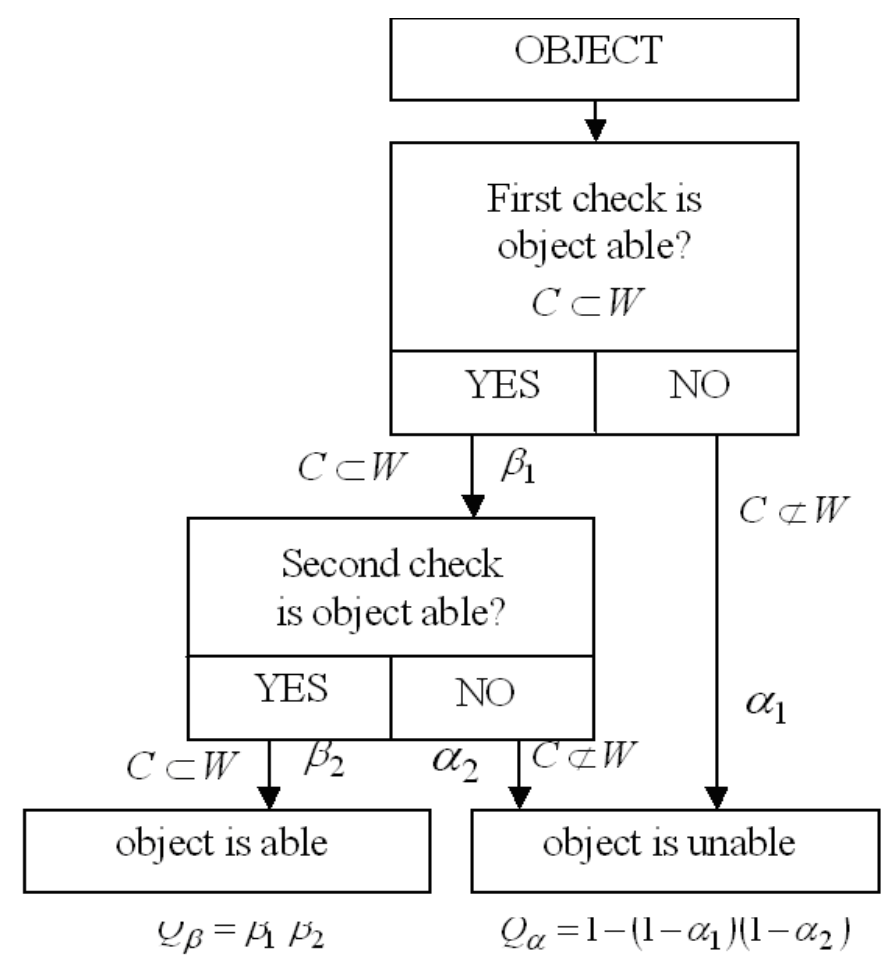

Figure 3. Illustration of the strategy No 3 (Table 1). 


\section{The reliability factors for $\mathrm{ms}$ in the case of immediate failures}

The MS reliability factor $R_{m}(t)$ is the probability that an interruption of information transmission about the state of investigated object does not occur immediately. If we denote by $T_{m}$ the work time of MS to the moment when immediate failure occurs then the reliability function in general case may be written in the following form:

$$
R_{m}(t)=P\left(T_{m}>t_{o}\right)=\exp \left[-\int_{o}^{t} \lambda(\tau) d \tau\right]
$$

where: $R_{m}(t)$ - reliability function,

$\lambda_{m}(t)$ - failure rate function,

$Q_{m}(t)=1-R_{m}(t)$ - unreliability function.

The expected value of the work time of MS to the moment of immediate failure occurrence is given by formula:

$$
E\left[T_{m}\right]=\overline{T_{m}}=\int_{o}^{\infty} R(t) d t
$$

For example, in the case of Weibule's distribution of random variable $T_{m}$, which is the most common in practice, we obtain:

$$
\lambda(t)=\lambda \alpha t^{\alpha-1}
$$

when: $\quad \alpha=1$ then $\lambda(t)=$ const.

$\alpha<1$ then $\lambda(t)=$ const is decreasing function,

$\alpha>1$ then $\lambda(t)=$ const is increasing function.

\section{The reliability factors for MS in the case of gradual failures}

Each MS is characterized by appropriate properties, which determine the quality of its functioning. In the use process of MS, these properties are changing, almost in undesirable direction, which can make reach the critical level, when the system is recognized as unable one. The changes of property depend on procedure of MS use and are continuous or discrete functions of time. In the simplest case, the time dependence of a property can be modeled as (Prochorenko \& Smirnov, 1976):

$$
C(t)=a+v t
$$

where: $\quad a=C(0)$ - the initial value of the property changes;

$v$ - speed of property changes.

Almost a and $\mathrm{v}$ are random variables. In Figure 4 various cases are shown: Figure $4 \mathrm{a}$ - the parameter $\mathrm{a}$ is random and $\mathrm{v}$ is deterministic; Figure $4 \mathrm{~b}$. - the parameter $\mathrm{a}$ is deterministic and $\mathrm{v}$ is random. 
a)

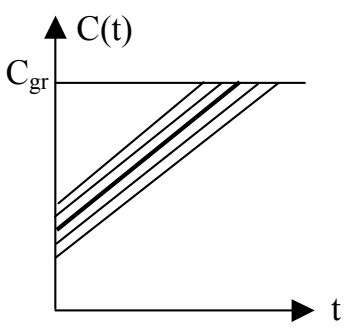

b)

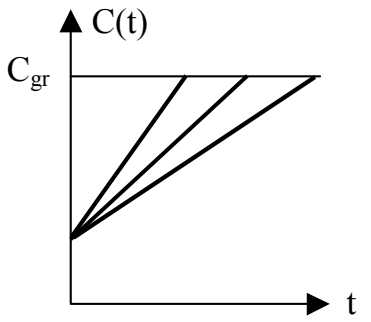

Fig. 4 Typical run of linear random process causing MS to failure (a) uniform; (b) fan-shaped.

When the parameters $\mathrm{a}$ and $\mathrm{v}$ have the normal distribution $N\left(m_{a}, \sigma_{a}\right)$ and $N\left(m_{v}, \sigma_{v}\right)$ and are independent then $C(t)$ have also normal distribution $N\left[m_{c}(t), \sigma_{c}(t)\right]$ with parameters:

$$
\begin{aligned}
& m_{c}(t)=m_{a}+m_{v} t \\
& \sigma_{c}^{2}(t)=\sigma_{a}^{2}+\left(\sigma_{v} t\right)^{2}
\end{aligned}
$$

The system is reliable when property $C(t)$ does not exceed a limit value:

$-\bar{C}_{g r}$ - upper limit

$-\underline{C}_{g r}$ - lower limit

$$
R_{g}(t)=\left[\underline{C}_{g r}<C(t)<\bar{C}_{g r}\right]
$$

In Figure 5 the failure rate functions in the case of immediate failures $(\lambda=$ const $)$ and in the case of gradual failures $\lambda_{g}(t)$ are shown.

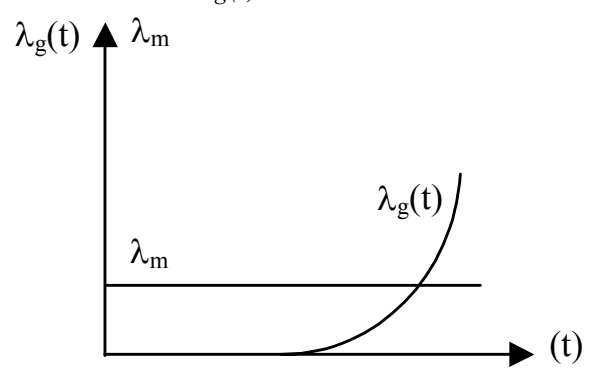

Fig. 5 The failure rate functions in the cases of immediate and gradual failures.

In the first period predominate immediate failures which occur with failure rate $\lambda_{m}$. In the final period (after time in which $\left.\lambda_{g}\left(t_{g}\right)=\lambda_{m}\right)$ the gradual failures dominate. In Figure 6 . the function of reliability affectivity $E_{n}(t)$ is shown. 


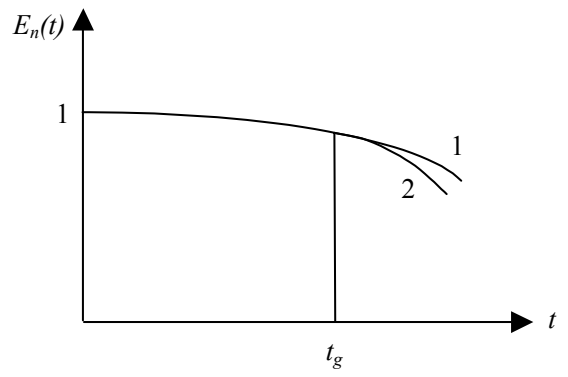

Fig 6 The reliability affectivity function:

1 - without gradual failures; 2 - taking into account gradual failures.

If we make the preventive exchange in moment $t_{g}$, the influence of gradual failures on the work of MS is negligible.

\section{Conclusion}

Effectivity of the system considered in the paper depends on such parameters as $\alpha$ and $\beta$ as well as $R_{s}$ and $R_{m}$. The first and the second type of errors can be decreased by the choice of proper strategy of checks.

Decreasing errors will diminish in undesired results of these errors. Similarly failure of measuring system can cause lack of information about the investigated object state, what also may cause undesired results. Reliability of the measuring system may be increased by extra checks.

The research project is financed from the Polish Science budget.

\section{References}

1. Jaźwiński J., Migdalski J., Wieremiejczyk W. Acta IMEKO, 1973, 1: 181-195.

2. Jaźwiński J., Ważyńska-Fiok K. Effectivity of measuring systems with surplus structure. XIII IMEKO World Congress from Measurement to Innovation, Torino, 1994, 2: 905-909.

3. Jaźwiński J., Ważyńska-Fiok K. Effectivity of measuring systems in Safety Aspects. State and Advances of Measurement and Instrumentation Science, TC1 and TC7 Colloquium, City University London, 1993a: 187-192.

4. Jaźwiński, J., Ważyńska-Fiok K. Effectivity of information systems. Proc. of $2^{\text {nd }}$ Polish National Conference Sztuczna Inteligencja (CJR '92), Siedlce, 1992.

5. Jaźwiński, J., Ważyńska-Fiok, K. Sztuczna Inteligencja. Proc. III Polish National Conference (CJR'93), Siedlce, 1993b: 233-237.

6. Jaźwiński, J., Ważyńska-Fiok, K. Problems of reliability of selected measuring systems. $5^{\text {th }}$ International IMEKO TC-4 Colloquium, Vienna, 1992. 
7. Prochorenko V. A., Smirnov A. N. Forecasting of system quality. Nauka i Technika, Mińsk, 1976.

8. Szpytko J.: Ksztattowanie procesu eksploatacji środków transportu bliskiego. Monografia, Biblioteka Problemów Eksploatacji, ITE, Kraków - Radom, 2004.

9. Wiśniewski K. About errors in alternate classification. Przegląd Statystyczny, 1961, 8 (3): 305-321.

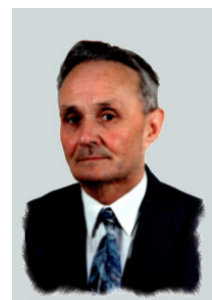

Professor Jerzy Jaźwiński (born in1927, Torczyn). Scientific Worker of Air Force Institute of Technology. Field of science: aviation transport, reliability, safety. Author and co-author of over 200 publications and books. Co-organizer of conferences: "Reliability in transport", "Safety of the systems", "Safety and Reliability KONBiN", "Annual winter schools on reliability". Activity in the following organizations: Polish Cybernetics Society, Committee of Transport of Polish Academy of Sciences, Committee of Mashine Building of Polish Academy of Sciences, Team of Reliability of the Section of Exploitation of the Committee of Mashine Building (Polish Academy of Sciences), Committee of Scientific Investigations - Team of Transport, Society of Reliability and Safety

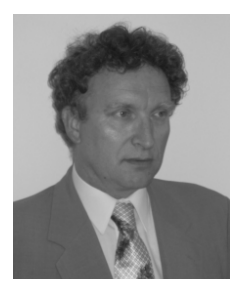

Prof. Dr hab. CEng. Janusz SZPYTKO, AGH University of Science and Technology, Faculty of Mechanical Engineering and Robo-tics. Specialist in designing and exploitation of transport systems and devices, automatics, safety and reliability, monitoring and diagnostics, decision making systems, telematics. Author or co-author of more then 300 publications, both in Polish and English. Member of: STST KT PAN, TC IFAC, SEFI, ISPE, PTD, PTB, PSRA, ISA, SITPH and others. Visiting professor at the universities in: UK, France, Canada, Italy, Greece, Canada, Laos. Coordinator and member of several R\&D projects both national and international. Organizer and member of several scientific and programme committees of international and national conferences and symposiums.

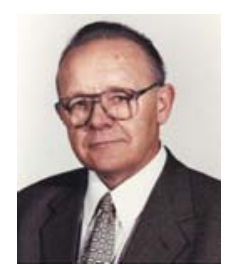

Dr. Józef Żurek, professor at Air Force Institute of Technology in Warsaw. Specialisation: mechanical engineering and machine operation/maintenance, transport, systems safety and reliability. Author and co-author of over 97 publications and books. Co-organizer of conferences: "Reliability in transport", "Safety of the systems", "Safety and Reliability KONBiN", "Annual winter schools on reliability". 